\title{
Model Structure of Islamic Guidance and Counseling in the Healing Process of Inpatients
}

\author{
Agus Riyadi, Yunika Indah Wigati
}

Universitas Islam Negeri Walisongo Semarang agus.riyadi@walisongo.ac.id

Submitted: 2019-08-26, Revised: 2019-11-13, Accepted: 2019-12-01

\begin{abstract}
Studies on spiritual guidance services for patients in hospitals have been widely discussed. The result of those studies shows that hospital care must be holistic-comprehensive following WHO standards, which include bio-psycho-socio-spiritual. One of the four components is that the spiritual aspect is non-negotiable because it can support treatment and motivate the patient to heal. This study aims to answer (1) how the medical and spiritual needs of inpatients go to the healing process, (2) how to structure Islamic guidance and counseling models for inpatient healing in hospitals. This study is a qualitative field research. The data were collected throughseveral techniques; observation, interview, and documentation. The results show that the medical and spiritual needs of patients at the hospital become one of the most important factors in the healing process. Therefore, suggested services to inpatients provided by hospitals are not only medical aspects butalso psychological supports, as well as social and spiritual aspects. This four-aspect approach is called holisticcomprehensive healing. Thus, it is suggested that the structure of Islamic guidance and counseling models in hospitals are 1) al-Hikmah model, 2) al Mauizhoh al Hasanah model, and 3) Good mujadalah.
\end{abstract}

Keywords: Islamic Guidance and Counseling; Inpatients; Patients in Hospitals

\section{Introduction}

The importance of the spiritual aspect in supporting treatment and motivating the patient's healing is non-negotiable, various research results prove that the spiritual can affect the patient's health (Aryanto, 2017). Psychologically, if the spiritual fulfillment of the patient is not fulfilled, it will result in a condition that is spiritual deficit to spiritual distress(Plante \& Thoresen, 2007).

The condition of patients being treated in hospitals requires special attention, such as non-medical attention in the form of holistic-comprehensive spiritual assistance services carried out by an expert in their field, focused on aspects of the patient's spiritual needs, programmed in a program independently, planned in each implementation, and systematic. Patients must also get motivation, support, suggestion, empathy and various matters concerning the psychological aspects of the patient's self (Basit \& Wachid, 2006). This type of service is not a nursing care service, but the service is guidance and counseling, as the target is Muslim patients, the guidance and counseling must be nuanced with guidance and counseling sourced from the Koran and Hadith as well as books- Islamic book (Riyadi, 2012).

The model of implementing guidance and counseling in hospitals for inpatients certainly has a fundamental difference with counseling in formal educational institutions and other institutions that have counseling services. But these differences are not significant both in terms of methods, media, and material. Indeed the implementation of guidance that there are differences lies in the implementation of work, understanding the patient's condition and patient's secrets as a client, work practices in the form of a team simultaneously, counseling sessions are on average shorter so that it is called a single session or counseling that is short (Arifin, 2012). All of this can be understood because the existing services of hospitals have fast and strict work regulations, little time, and a work atmosphere that is patterned in various forms of fixed work procedures that have been set.

Various research results from within and outside the country show the same indicators that the implementation of guidance and counseling in hospitals is different from the 
guidance available in formal education institutions. It can be seen that the implementation of guidance and counseling in hospitals is more likely to pay attention to the importance of the spiritual aspects in supporting treatment and motivating the healing of patients because spiritual aspects can affect the healing of hospitalized patients (Plante \& Thoresen, 2007). Medical and spiritual dimensions can cure the condition of patients (Balboni et al., 2007; D’Souza \& Rodrigo, 2004).

Implementation of guidance and counseling in hospitals based on the description above has a strategic role in supporting and motivating patient recovery and can find the core problems faced by patients. Based on research, the process of Islamic spiritual guidance for problems in hospitals is still lacking. That can be seen among others; First, the implementation of guidance to patients is limited to giving prayers, reminding about patience and guidance of worship only and have not been able to find the core problems faced by patients. Second, when viewed in the Islamic spiritual guidance workflow, there is no "problem record data" form of the patient, which is used to record the implementation of the guidance and counseling, which can cause the repetition of questions in the guidance process. Third, the approach developed in carrying out Islamic spiritual guidance is still dominated by the normative approach, so the method that has been used so far is still burdened by a lot of religious content. Patients need a psychological touch, but the officer who provides spiritual guidance seems to influence the patient. The clerk gives more lectures to the patient, while the patient is very passive in accepting what he conveys. Fourth, the application of Islamic spiritual guidance does not pay attention to the patient's age, psychological aspects, type of illness suffered by the patient, patient characteristics, and social and economic status of the patient.

Based on the description and explanation above, this article aims to answer (1) how the medical and spiritual needs of inpatients go to the healing process, (2) how to structure the Islamic guidance and counseling model for inpatient healing in hospitals.

\section{Methods}

This research is a qualitative study. This qualitative study was caused by examining the condition of natural objects about the spiritual needs of patients as well as Islamic guidance and counseling for patients at Roemani Muhammadiyah Hospital Semarang. This study uses the phenomenology method by examining the experiences experienced by patients at Roemani Muhammadiyah Hospital Semarang. The intended experience is what is experienced by the patient, such as anxiety, anxiety, sadness, fear, despair, and pessimism about his illness. Through this phenomenological method is intended to get an understanding of various situations, conditions, and phenomena from the research site. This phenomenological research is to understand a phenomenon experienced by patients to the level of "confidence" of the patient concerned: the data collection techniques through; observation, interview, and documentation.

Field data will be analyzed holistically to produce comprehensive research, as the approach is the Islamic guidance and counseling approach, psychological approach, and da'wah. Through these three approaches, it is expected to get a deep and broad understanding relationship so that the research findings from a valid theory and have a high level of truth.

\section{Results and Discussion \\ Medical and Spiritual Needs of Inpatients Towards a Healing Process}

The presence of inpatients in hospitals has received medical services, especially services from doctors and nurses. However, medical facilities are still not enough to meet the needs of patients who are hospitalized. Non-medical services are needed to meet hospital service requirements. Non-medical services are anything that is out of medical reach or not 
related to doctors or nurses because it is related to spiritual needs. Spiritual contains several meanings, namely: (1) relating to spirit (2) religious, relating to belief, faith, goodness, concerning divine values, (3) relating to mental ie physical or physical(Hood Jr, Hill, \& Spilka, 2018).

In the initial study, spirituality and religion are often understood as the same two terms. But with the development of science, spirituality has been regarded as a special personality (connotations) of a person's beliefs or beliefs that are more personal, not too dogmatic, more open to new paradigms and various influences, and more pluralistic than beliefs interpreted or based on religion- religion that is believed by most people(Muttaqin, 2012).

Talking about the spiritual aspect, of course, has a direction and purpose that will continuously make a person's wisdom and strength to get close to God, and the universe will eliminate illusions that come from the sense organs, feelings, and thoughts. Various parties argue that the spiritual aspect has two directions, first in the course of the upward process that can make the emergence of internal power and overhaul one's relationship with God, the second direction of the downward process which is indicated by an increase in one's physical reality due to internal changes(Puspita, 2009). The difference is a change will occur in a person with increased understanding and self-awareness, where the divine values in it will be manifested out through self-practice and self-independence.

According to Nico Syukur, there are significant differences between spiritual and religious. Spiritual is self-awareness and individual awareness about the origin and purpose and destiny of a person. Whereas religious is an absolute and indispensable truth from a life that has physical manifestations above the world. In addition, religiosity can also be interpreted as the practice of certain behaviors related to belief systems(Kinasih \& Wahyuningsih, 2012).

Overall the spectrum of needs of each inpatient includes bio-psycho-socio-spiritual needs. All aspects of these needs must be met in a balanced manner and each patient is entitled to their fulfillment. In the Nursing Assessment Data Record (RDPK) sheet at the hospital, the details of each According to Nico Syukur, there are significant differences between spiritual and religious. Spiritual is self-awareness and individual awareness about the origin and purpose and destiny of a person. Whereas religious is an absolute and indispensable truth from a life that has physical manifestations above the world. In addition, religiosity can also be interpreted as the practice of certain behaviors related to the belief system needs are obtained from a series of diagnostic processes on the state of each patient's laboratory examination, and interviews with patients. The biological needs of patients are a variety of physical needs of patients who are actually very broad. However, for the sake of care aspects of the biological needs of patients who are guarded to be fulfilled only those related to medical interests such as maintaining the needs of vital parts of the patient for example: diet, respiratory system, cardiovascular system to maintain the needs of the digestive system, endocrine system, urinary system and reproduction, nervous system, sleep needs, rest, and others (Wahab, 2013).

The psychological needs are how to maintain the need for patients to feel free from various psychological pressures that directly affect the pain. This is also related to the needs of the social aspects where the hospital is obliged to maintain patient relationships with family, others, and the environment, especially as long as he is in care. Fulfillment of the three aspects above namely bio-psycho-social is actually not too complicated when compared to meeting the needs of the other aspects, namely the spiritual aspect. In the spectrum of inpatient needs, indeed the spiritual needs in the RDPK sheet in each hospital are on the final sheet with aspects of the study that are unclear, not detailed, usually only covering two aspects, namely religious and religious beliefs, and healthy, sick beliefs , and recovery is 
difficult to do the assessment. Unlike the many other and detailed aspects of the assessment, the spiritual needs of the inpatient are no less extensive than the other three needs. It is only possible because the assessment of aspects of this spiritual need has not yet been done by many other factors because spiritual needs are abstract, distinctive, and personal (Satria, 2012).

According to V.B. Carson's spiritual need is the need to gain understanding and build confidence in fulfilling the obligations prescribed by religion, the need to get forgiveness, to establish friendly relations, and to be full of trust in everything that God commands. Meanwhile, according to Howard Clinebell there are ten basic spiritual needs of humans, namely the need for 1) basic trust that is continuously ongoing to motivate and awaken spiritual awareness, 2) The meaning of life, the purpose of life that can make a balanced relationship between humans and God, 3) Commitment in worship and relate in daily life with fellow human beings, 4) Regular spiritual replenishment as a relationship with a Spiritual Source, 5) Free of sin with God and guilt with humans, 6) Self-acceptance and selfesteem, 7) Having a sense of security, and guaranteed safety against the desired expectations, 8) Achieved a higher degree and dignity and live as a whole person, 9) can maintain good relations with nature and fellow humans, 10) Community life filled with values set in religion(Muttaqin, 2012).

According to the North American Nursing Diagnosis Association (NANDA) International Standards for Spiritual Nursing Care there are nine aspects of spiritual needs in patients, namely: (1) understanding of worship practices in the sick, (2) ritual worship practices activities (3) emotional stability, (4) ) good social interaction skills (5) have hope, (6) spiritual well-being (7) prosperity, (8) quality life, (9) dying care or death guidance in order to achieve the death of husn al-khatimah. Thus the patient's spiritual needs are as broad as the spiritual meaning itself (Kinasih \& Wahyuningsih, 2012).

Related to this, the existence of Islamic counseling guidance services is to help the problems faced by patients who are experiencing various kinds of problems both psychological, social and religious problems in addition to the physical illness suffered. Islamic guidance and counseling services in the form of giving religious advice, motivation to solving the personal root problems of the patient and also the family are expected to be able to overcome problems outside the medical term so that in the end the patient can achieve complete health from both physical, psychological, social and social aspects. spiritual.

\section{Model Structure of Islamic Guidance and Counseling for the Healing of Inpatients in Hospitals}

The structure of a model will be determined by the components that are in the model. Therefore the formulation of the model is based on several expert opinions as a reference. According to Gerald Corey the components in a counseling and psychotherapy model include: (1) basics and introductions, (2) key concepts, (3) therapeutic processes, and (4) applications that contain counseling and psychotherapy techniques and procedures(Corey, 2017). Shertzer \& Stone (1980) Formulate the components of the counseling model consisting of: (1) historical context, (2) basic assumptions, (3) advantages and disadvantages, (4) results and implications. According to Sue Marshall important components in counseling and psychotherapy consist of: ( 1) background and development, (2) basic philosophical concepts, (3) counseling process, (4) techniques and implementation(Marshall, 2004). Referring to the service component of the guidance and counseling program in accordance with Munro and Kottman (1979: 112), there are four types of evolution that must be provided, namely: (1) basic service assistance, (2) responsive service assistance, (3) planning assistance individual services, and (4) adequate support systems. 
While in the perspective of Islamic guidance and counseling science, the model of guidance and counseling is developed based on existing theories. The Islamic guidance and counseling model itself was developed based on the Qur'an and the hadiths which form the foundation of developing Islamic guidance and counseling theories (). Both of these figures agreed that the Islamic guidance and counseling model was developed based on the Qur'an Surah An Nahl 125: Meaning "Leave your Lord's way with wisdom and good lessons and refute them in a good manner. Verily, your Lord, He knows more about anyone who has strayed from his path and He knows better those who are guided. " Al Hikmah Model

Al wisdom is 1) a wise attitude that is based on the principle of togetherness and conformity, the principle of balance, the principle of compassion, and keeps away the ugliness and the principle of love and affection; 2) the power of God who instills the values of goodness, positive energy, change, motivation and healing; 3) strength in carrying out religious observances; 4) Intelligence obtained from God so that with this intelligence various kinds of life problems can be solved.

Various model formulations in wisdom theory are a basis that can be used as a determinant and guide to provide various inputs to clients who really really need help in developing their qualities so that they can achieve a positive self-image and can reach the test with a strong and independent.

Techniques that can be done in the implementation of Islamic guidance and counseling with the wisdom model are as follows: 1) Knowing the various causes of problems faced by patients and solving them with a religious and psychological approach, 2). Making good relations with patients by providing assistance to understand the problems that are happening to him, providing various alternative ways to be able to solve the problem, and helping patients to make self-corrections related to the behavior he had done, 3) Helping patients to understand the teachings of Islam and practice it in daily life in order to get peace and happiness in life in the world and the hereafter, 4) This model emphasizes counselors to be brave but careful, there needs to be closeness to family patterns and exemplify exemplary.

1. Model Al Mauizhoh Al Hasanah

Munzier Suparta defines Al Mauizhoh Al Hasanah as words which contain elements of kindness, actions, guidance, moral education, teaching, stories, good news, good wills that are used as a foundation in social life, religion so that life is safe in the world and the afterlife. Islamic guidance and counseling in this way can be developed by taking stories from the lives of the Prophets, Apostles and Salafu Salih and Auliya Allah. With this kind of model, the clergyman or counselor can find out how God provides guidance and directs positive thinking, how to feel, how to behave and deal with various life problems of life that each day alternates. It also can find out how they can build the closeness, obedience and piety of God; develop their potential and find their self-image, and how they can solve problems that can destroy the mental and spiritual (Suparta, 2003).

The concept of guidance and counseling with this model emphasizes more on giving direction to patients using the example of the process of the prophets, namely how the prophets, messengers, and the Auliya Allah make improvements, changes in personality problems so that they can become perfect human beings or humans.

2. Mujadalah model is good

The term Al Mujadalah can be interpreted as a discussion to gain understanding. This is usually done by two or more people in synergy. The hope is that there is no understanding dispute, does not lead to hostility and the opponent can accept the decision of the results discussed (Suparta, 2003: 20). This model was developed for a client who is in balance, that is, the client wants to find a truth that can convince himself, which so far he has problems having difficulty making decisions of two or more things, while he assumes that the two or more are good and right for him. Yet according to the counselor's view it can endanger the 
development of his soul, mind, emotional and environment (Suparta, 2003: 16). Hamdani Bakran Adz-Dzaky also explained, the typical principles of this theory are: 1) There must be a high level of patience from the counselor, 2) The counselor must master the root of the problem and its treatment well, 3) Mutual respect and respect, 4 ) Not aiming at toppling or defeating the client, but guiding the client to find the truth, 5) Sense of brotherhood and loving saying, 6) Speech and language that is easily understood and refined, 7) Does not offend the client's feelings, 8) Expresses the arguments of al- Quran and As-Sunnah clearly and precisely, 9) True Christianity (Adz-Dzaky, 2002)

This model emphasizes individuals who need strength in beliefs and want to dispel doubts, misgivings and negative prejudices about divine truth.

\section{Conclusions and Suggestions}

The medical and spiritual needs of patients at the hospital are one of the most important factors in the healing process. Therefore, hospitals in providing services to inpatients are not only medical aspects, but are also supported by psychological, social and spiritual aspects. This four-aspect approach is called holistic-comprehensive healing. Islamic guidance and counseling is a spiritual aspect for the complete healing of the patient so that the patient does not experience a spiritual deficit. The structure of Islamic guidance and counseling models in hospitals is 1) al Hikmah model, 2) al Mauizhoh al Hasanah model, 3) Mujadalah is good.

\section{References}

Arifin, I. Z. (2012). Bimbingan dan Konseling Islam untuk Pasien Rawat Inap di Rumah Sakit. Ilmu Dakwah: Academic Journal for Homiletic Studies, 6(1), 170-194.

Aryanto, I. (2017). Pelaksanaan Bimbingan Perawatan Rohani Islam (Warois) Untuk Memenuhi Kebutuhan Spiritual Pasien. Irsyad: Jurnal Bimbingan, Penyuluhan, Konseling, Dan Psikoterapi Islam, 5(3), 241-260.

Balboni, T. A., Vanderwerker, L. C., Block, S. D., Paulk, M. E., Lathan, C. S., Peteet, J. R., \& Prigerson, H. G. (2007). Religiousness and spiritual support among advanced cancer patients and associations with end-of-life treatment preferences and quality of life. Journal of Clinical Oncology: Official Journal of the American Society of Clinical Oncology, 25(5), 555.

Basit, A., \& Wachid, A. (2006). Wacana Dakwah Kontemporer. STAIN Purwokerto Press.

Corey, G. (2017). Theory and practice of counseling and psychotherapy. Nelson Education.

D'Souza, R. F., \& Rodrigo, A. (2004). Spiritually augmented cognitive behavioural therapy. Australasian Psychiatry, 12(2), 148-152.

Hood Jr, R. W., Hill, P. C., \& Spilka, B. (2018). The psychology of religion: An empirical approach. Guilford Publications.

Kinasih, K. D., \& Wahyuningsih, A. (2012). Peran Pendampingan Spiritual Terhadap Motivasi Kesembuhan Pada Pasien Lanjut Usia. Jurnal Stikes, 5(1), 1-10.

Marshall, S. (2004). Difference and discrimination in psychotherapy and counselling. Sage.

Muttaqin, A. (2012). Islam and The Changing Meaning of Spiritualitas and Spiritual in Contemporary Indonesia. Al-Jami'ah: Journal of Islamic Studies, 50(1), 23-56. 
Plante, T. G., \& Thoresen, C. E. (2007). Spirit, science, and health: How the spiritual mind fuels physical wellness. Praeger Publishers/Greenwood Publishing Group.

Puspita, I. (2009). Aplikasi Asuhan Keperawatan Spiritual Muslim Di R. Firdaus III RS. Alislam Bandung. Majalah Keperawatan Unpad, 11(20).

Riyadi, A. (2012). Dakwah terhadap Pasien (Telaah terhadap Model Dakwah melalui Sistem Layanan Bimbingan Rohani Islam di Rumah Sakit). Dalam Konseling Religi: Jurnal Bimbingan Konseling Islam, 3(2).

Wahab, M.N.A and Urme B S, (2013). "The Effects of Islamic Spiritual Activities on PsychoPhysiological Performance". Journal of Educational. Health and Community Psychology, 2 (2).

Satria, B, et al. (2012) "Development of a Community-Based Spiritual Life Review Program for Promoting Resilience of Elders Residing in Disaster-Prone Areas", Nurse Media Journal of Nursing, 2, (2).

Suparta, M dan Hefni, Harjani (ed). (2003). Metode Dakwah. Jakarta: Rahmat Semesta.

Adz-Dzaky, H. B (2002) Konseling dan Psikoterapi Islam Penerapan Metode Sufistik. Yogayakarta: Fajar Pustaka. 
